\title{
The Effect of Some Plant Extracts Against Proteus spp and Klebsiella spp Bacteria and Comparing Them with Antibiotic
}

\author{
Roqia Ahmed Abbas \\ Biology department, College of Pure Science, University of Diyala, Baquba, Diyala, Iraq \\ Aseel Adnan Al-khazreje \\ Biology department, College of Pure Science, University of Diyala, Baquba, Diyala, Iraq \\ Roaa Adnan Hussein \\ Bilad Alrafidain University Collage, Baquba, Diyala, Iraq
}

\begin{abstract}
The study was conducted to determine the inhibitory effectiveness of different concentrations of lemon (Citrus lemon) and ginger (Zingiberofficinale) extracts on the Klebsiella and Proteus Bacteria. The outcome of this work was that the Klebsiella showed the highest inhibition at $75 \%$ concentration, $24 \mathrm{~mm}$ of lemon extract and $20 \mathrm{~mm}$ of ginger extract, while the proteus recorded the highest inhibition at $75 \%$ concentration of $21 \mathrm{~mm}$ of lemon extract and $18 \mathrm{~mm}$ of ginger extract. This conclusion was evaluated using Agar well-diffusion method; the results were compared with the effect of some antibiotics, mix lemon-ginger extract in equal proportions with the same previous concentrations, Different diameters were given and this was evident on Klebsiella and Proteus bacteria. The extract gave a strong efficacy at $75 \%$ concentration $28.25 \mathrm{~mm}$ over the antimicrobial action that was used in int the study by respectively the highest inhibitor of Erythromycin $20 \mathrm{~mm}$ on Klebsiella, while anti-Amikacin was $18 \mathrm{~mm}$ on Proteus. The reached results were encouraging to conclude that in spite of the difference in the extent of their effect in inhibiting the bacteria growth. The lemon/ginger extract had a larger effect for inhibiting. Keywords: lemon, ginger, extract, antibiotic, inhibiting bacteria.
\end{abstract}

DOI: $10.7176 / \mathrm{JBAH} / 9-6-06$

Publication date:March $31^{\text {st }} 2019$

\section{Introduction}

Antimicrobial drugs were of interest to researchers in the 20th century due its effect to reduce the mortality rate and to treatment of the resulting problems that caused by microorganisms, but at the end of the century studies have proven that the bacteria can develop antibiotic resistance when adapt and grow under presence of these antibiotics for several generations, and show this resistance through the interchange of genetic material of resistance among different types of bacteria. Scientists concluded that the excessive use of these drugs is the main reason to arise resistant medicine strains (Uwaezuoke and Ariatu, 2004)

Medicinal plants have a long history of use around the world, According to the World Health Organization (W.H.O.) about $80 \%$ of the world's nation rely mainly on folk therapies which involve the use of plant extracts (Sofowora,1999).

Ginger Zingiber officinale Roscoe, belong to Zingiberacae family is one of the famous spices all over the world. Ginger is the underground rhizome spread cultivation in South East Asia, West Africa and the Caribbean (Weiss, 1997; McGee, 2004). In addition to the nutritional values Ginger has a medicinal important (Kumar et al, 2011) .Many research has been showed that the ginger extract also have antimicrobial activity and anti-oxidant properties against both positive and negative gram bacteria and fungi. Ginger has inhibition actin to the growth of Escherichia coli, Proteus sp, Salmonella Staphylococci, and Streptococci (White, 2007). Ginger is a plant used in the treatment of diseases by conventional methods. Studies and research have shown that it has been effective in preventing and treating a wide range of diseases, including various infections and its ability to prevent cancerous growth (Akram et al., 2011).

Lemon Citrus limon (L.) Osbeck belong to Rutaceae family grown all over the world, consider a medicinal plant which it having anticancer activities and the antibacterial potential in crude extract of different its parts against significant bacterial strains has been confirmed (Kawaii,2000). Citrus flavonoids have a big spectrum of biological activity including antibacterial, antifungal, and anticancer activities (Burt, 2004). Thus, ginger and lemon consider one of these protection lines against natural enemies like bacterial and fungal pathogens. This has been led many of antimicrobial researchers to refer to the use medicinal plants for many reasons including their availability, easily obtained, low cost, and safe with rare side effects (Deboer et al., 2005). Lemon acid is not less important than ginger in medical treatments that has been used additionally it is a natural source of vitamin $\mathrm{C}$, which causes scurvy reduction and is an immune stimulant (Ncube et al, 2008).

Hence, the idea of this study where it aims to investigate new therapeutic alternatives against bacteria and the selection of plant extract which has the strongest effects on these germs so it focuses two types of plants 
Ginger and lemon.

\section{Materials and Methods \\ Plant collection \\ 1.Preparing of plants}

Ginger and lemon was obtained from the local markets, cleaned, washed with distilled water, ginger peeled and sliced and then dried at room temperature for three weeks, then grinded with an electric grinder. The powder was stored in a glass bottle in the refrigerator, while lemon's fruits were cut into halves and its juice was extracted by squeezing, then dried and packaged in a glass bottle and kept at a temperature until use.

\section{Preparation of the Extract}

$10 \mathrm{~g}$ of dry ginger powder mixed with $200 \mathrm{ml}$ of sterilized water. The mixture was blended with a magnetic mixer for 15 minutes, leaving the solution for a period to precipitate. The solution was filtered and the sediment was neglected. The strained substance was separated by a centrifuge at $3000 \mathrm{rpm}$ for 10 minutes to precipitate the suspended plant parts and obtain pure solution. The solution was concentrated using rotary evaporator at $40^{\circ} \mathrm{C}$ until it became dry and then stored in the refrigerator. The same process was repeated with lemon powder using the same method. (Boham, Kocipai, 1974).

\section{Preparation of Concentrations.}

Aqueous extract of ginger and lemon were prepared individually dilution with different concentrations are: $25 \%$, $50 \%$, and $75 \%$ (Boham, 1974). Prepare concentration without dilution from stock ginger and lemon extract with $50: 50 \mathrm{~g}$ from each sample, then prepared $25 \%, 50 \%$ and $75 \%$.

\section{Pathogenic Bacterial Isolates}

Isolate Klebsiella and Proteus bacteria they are negative gram stain at the laboratories of Baqouba Instructional Hospital, from the infected patients as urine isolation. Nutrient broth and Nutrient agar were used in the development and activation of pathogenic bacterial isolates. The Muller Hinton agar medium was used to determine the effect of plant extracts on the bacteria after activating the bacterial plantations for 24 hours using the diffusion method and three replicates were applied for each plate, incubated at $37^{\circ} \mathrm{C}$ for 24 hours. The effectiveness of the plant extracts was determined by measuring the diameter of the inhibition zone, which is free of bacterial growth.

\section{Antibiotics examination}

To study the effect of antibiotics in bacterial growth, the method that was used to determine the effect of antibiotics. Tetracycline, Amikacin and Erythromycin were used according to Reeves (1987)

\section{Chemical statements}

In order to identify the most important chemical components of the crude extract of ginger and lemon plants, a chemical analysis was carried out by taking $100 \mathrm{~g}$ of dry powder for each sample with adding $200 \mathrm{ml}$ of distilled water and then dried at $50^{\circ} \mathrm{C}$ for 12 hours and the precipitate was diluted in $200 \mathrm{ml}$ of distilled water again and was used in the chemical examinations for each gram of Alkaloids, Flavonoids, Terpenaids, Steroids, Saponins, Tannis according to dependable Harborne ( 1973) method.

\section{Results and discussion}

The results of the experiment showed different effects of the active compounds of the ginger and lemon plants in the growth of klebsiella and proteus bacteria isolates from urine infected patients. There is significant inhibition in the bacterial species under study, which was revealed by One Way Anova analysis with a probability level of 0.05 .

As shown in Table (1), the results clarifythe effect of Aqueous extracts of ginger and lemon against the bacteria under study, where the higher the concentration of the extract used, the greater the inhibitory effect. This effect was evident against Klebsiella bacteria rather than Proteus bacteria where the bacterial growth inhibition of Klebsiella and Proteus bacteria was increased by $(24,21) \mathrm{mm}$ respectively using lemon extract $(20,18) \mathrm{mm}$ respectively. This is the highest concentration used in the study compared with the concentration of $25 \%$, the lowest concentration used. The results showed a difference in the inhibitory activity of the lemon extract and the ginger extract. Where the diameter of the fixation Klebsiellaand Proteus were reduced by (17, 14) $\mathrm{mm}$ respectively with $25 \%$ concentration of lemon extract while the inhibitory diameter of Klebsiella and Proteus was $(12,10) \mathrm{mm}$ respectively for the same concentration of ginger extract, which is less effective than lemongrass extract.

This variation in the inhibitory effect of the extract may be due to the fact that they contain varying levels of acid, especially lemons, so that the $\mathrm{pH}$ value will be acidic and it will affect the charge of amino acids that are constituent proteins associated with the peptidoclacan, which is a component of the bacterial cell wall. It also affects the active sites of the wall enzymes, leading to a defect in enzyme functions, as agreed by Atlas (1995) and Albayati (2010). 
Table (1) Diameters Areas inhibiting the growth of bacteria treated with different concentrations of plant extracts

\begin{tabular}{|c|c|c|c|c|c|c|}
\hline \multirow[t]{3}{*}{ Isolation } & \multicolumn{6}{|c|}{ Bacteria Inhibition Diameter(mm) } \\
\hline & \multicolumn{3}{|c|}{ Ginger Extract } & \multicolumn{3}{|c|}{ Lemon Extract } \\
\hline & $25 \%$ & $50 \%$ & $75 \%$ & $25 \%$ & $50 \%$ & $75 \%$ \\
\hline Klebsiella & 12 & 16 & 20 & 17 & 20 & 24 \\
\hline Proteus & 10 & 14 & 18 & 14 & 17 & 21 \\
\hline
\end{tabular}

The results of the study showed that the mixture of the extracts was highly effective against the growth of Klebsiella and Proteus bacteria. The bacteria started with the sensitivity at the concentration 25\%. As shown in Table (2) where the diameter of the bacterial inhibition Klebsiella and Proteus by $(20,18) \mathrm{mm}$ in the order of $25 \%$ concentration. In comparison with the same concentration of lemon extract and ginger extract in Table 1 , there is a difference between the inhibitory force of the extract together more than the inhibitory force of the extracts. $75 \%$ of the extract when combined gave the strength of the installation $(28,25) \mathrm{mm}$ for Klebsiella and Proteus respectively, while the same concentration gave a 20 to $18 \mathrm{~mm}$ inhibitory strength to the same bacteria. This may be due to the fact that lemon and ginger contain high alkaloids that interfere with the metabolic reactions (Tegos et al.2002), as shown in Table 3, as well as the containment of lemons on the tannins that are characterized by their inhibitory activity for bacterial growth (Al-Rawi\&Chakravarty, 1988). This may be due to the combination of active substances In the extract of lemon and ginger and their interaction together leading to the formation of a compound with strong effective effects on the bacterial growth of the species under study and this is consistent with (Grzanna et al.2005). The results explain that there is no significant differences among all the extracts used in the study against the Klebsiella bacteria. There were significant differences in lemon extract with ginger in Proteus bacteria at level 0.05, which is consistent with other studies in the same field (Albayati 2010).

Table .2 The biological efficacy of ginger and lemon blend at 50:50\%

\begin{tabular}{|l|c|c|c|c|}
\hline \multirow{2}{*}{ Isolation } & \multicolumn{2}{|c|}{ Bacteria Inhibition Diameter(mm) } & \multirow{2}{*}{ Average } \\
\cline { 2 - 4 } & $25 \%$ & $50 \%$ & $75 \%$ & \\
\hline Klebsiella & 20 & 24 & 28 & 24 \\
\hline Proteus & 18 & 21 & 25 & 21.3 \\
\hline
\end{tabular}

The results in table (2) showed that when the mixture ginger /lemon extract 50:50\% gave high results in the bacterial inhibition of the species under study. The rate of inhibited diameter of the concentrations in the Klebsiella bacteria gave the highest value $24 \mathrm{~mm}$ compared with the rate of diameter inhibition of Proteus bacteria at a value of $21.3 \mathrm{~mm}$. This may be due to the similarity of the active substances in the extracts and their interaction together, leading to the formation of a compound with strong effects on the bacterial growth of the species. This is consistent with Grzannaetal.(2005).

Table (3) The qualitative data of the active ingredients of plant extracts

\begin{tabular}{|l|c|c|}
\hline Active Substance & Ginger Extract & Lemon Extract \\
\hline Alkaline & + & + \\
\hline Tannins & - & + \\
\hline Phenol & + & + \\
\hline Turbine & + & + \\
\hline Volatile Oiles & + & + \\
\hline
\end{tabular}

Table (3) shows the most important qualitative chemical statements of some active ingredients in ginger and lemon extract ingredients as proven study containing extracts on alkaloids and tannins, phenols and terpenes and others which are effective materials anti-bacterial, this is consistent with the (Chrubasik, etal.2005), as these substances as inhibitors of the types of bacteria isolated from satisfactory injuries.

Table (4) Comparison of the biological efficacy of the extract blended with some antibiotics

\begin{tabular}{lcccc}
\hline Bacteria & Erythromycin & Amikacin & Tetracycline & Extract75\% \\
\hline Klebsiella & 20 & 10 & 10 & $\mathbf{2 8}$ \\
Proteus & 8 & 18 & 15 & $\mathbf{2 5}$ \\
\hline
\end{tabular}

The inhibitory effect of the mixed extract of ginger and lemon was compared with $75 \%$ concentration with antagonists TE(Tetracycline), AK(Amikacin), and E(Erythromycin) which is used extensively in the treatment of most bacterial infections. Table (4) shows that the mixed extract had a clear inhibitory effect of Klebsiella and Proteus, against the bacteria Klebsiella with a diameter of inhibitory (28)mm as superior to the work of antibiotics, TE, AK, E. In equal Proteus bacteria, where the extract recorded a high inhibitory effect of $25 \mathrm{~mm}$ inhibition compared to the inhibitory of antibiotics, TE, AK, E,. The efficiency of plant extracts exceeds antibiotic when it is used in a healthy and precise way, this is agree with (Kawail, etal.2000).

\section{References}

Uwaezuoke ,J.C.andAririatu , L.E.(2004).Asurvey of antibiotic resistant staphylococcus aureus strains from 
clinical sources on Owerri , J.Appl. Sci. Environ., 8(1):67-69.

Deboer, H.J.,Kool , A.,Berberg, W.R., Mziray, I., Hedberg and levenfors , J.J.(2005). Antifungal activity of some herbal remedies from tanzanias .J.Ethnopharmacol., 96:461-469.DoI:10.1016/J.jep.2004.09.035.

Alrubaye, Dawod J.(2013). The arabian encyclopedia of medicinal herbs. Vol:(1).p:261-262,p:555-556.

Boham,B.A.,Kocipai-Abyazan. (1974). Flavonoids and condonsed tannins from leaves of Hawaiian vaccinium and V.calyciniumpacific . Sci. 458-463.14.

Reeves ,D.S.;Phillips , I.;Williams , J.D. and Wise , R.(1987). Laborathods in antimicrobial. Churchill Livingstone .

Harborne,J.B.(1973)Phytochrmicalmethods.London.champrman and Hall. Ltd pp.49-188.

Albayati ,MayssonK.Abdul-latif M. JarwaH.Khudir .(2010).EVALUATION OF ZingiberofficinaeRosc. EXTRACTS AGAINSTPATHOGENICBACTERIA .Iraqi Journal of Science ,Vol:51,No3,P403-409.

Grzanna, R., Lindmark,L. and Frondoza,C.G.( 2005 ) . Ginger-an herbal medicinal product with broad antiinflammatory actions. J. Med. Food., 8: 125- 132 .

Kawaii,S.,Yasuhiko ， T.,Eriko,K.,Kazunori, $\quad$ O.,Masamichi, $\quad$ Y.,Merisaku, K.,chihirolto and Hiroshi,F.(2000)Quantitaive study of flavonoids in leaves of citrus plants Journal of Agricultural and food chemistry.48:3865-3871.

Chrubasik, S., Pittler,M.H. and Roufogalis,B.D. ( 2005 ). Zingiberisrhizome:Comprehensive review on the ginger effect and efficacy effect and efficacy profiles. Phytomedicine, 12: 684-701.

AkramRiazurRehman, M., NaveedAkhtar ,QaiserJabcen .(2011). Zingiberofficnale Roscoe ( pharmacological activity)Journal of Medicinal plants Research Vol:5(3),p344-348,4february.

Ncube , N.S.,Afolayan A.J.,Okoh , A.I.(2008). Assessment techniques of antimicrobial properties of natural compounds of plant origin current methods and future trends .African journal of Biotechnology ; 7(12):1797-180.

A, Sofowora, Introduction to medical plants and traditional medicine. Spectrum books limited, 2, (1999), 8-76.

S. Gupta and S. Ravishankar, A comparison of the antimicrobial activity of garlic, ginger, carrot, and turmeric pastes against Escherichia coli O157:H7 in laboratory buffer and ground beef. Foodborne Pathogens and Disease, 2 (4), (2005), 330-40.

B. White, Antimicrobial activity of ginger against different microorganisms: Physician, 75, (2007), 1689-1691.

P.V. Nielsen and R. Rios, Inhibition of fungal growth on bread by volatile compounds from spices and herbs and mustard essential oil. International Journal of Food Microbiology, 60(2-3), (2000), 219-229.

S.P. Nanir and B.B. Kadu, Effect of medicinal plant extracts on some fungi. ActaBotanicaIndica, 15(2), (1987), 170-175. A, Sofowora, Introduction to medical plants and traditional medicine. Spectrum books limited, 2 , (1999), 8-76.

G. Kumar, L. Kathie and K. V. B. Rao, A review on pharmacological and phytochemical properties of Zingiberofficinale Roscoe (Zingiberaceae), Journal of Pharmacy Research, 4(9), (2011), 2963-2966.

E. A. Weiss, Essential Oil Crops, CAB International, Oxon, UK and New York (1997), 76.

$\mathrm{H}$, McGee, On food and cooking, in H.McGee (Ed.), The science and lore of the kitchen. 2nd Edition. (New York, 2004) 425-426.

P. Utpala, A.K. Johny, V.A. Parthasarathy, K. Jayarajan and M.S. Madan, Diversity of ginger cultivation in India - a GIS study, Journal

Satoru Kawaii, Yasuhiko Tomono, Eriko Katase, Kazunori Ogawa, Masamichi Yano, et al. (2000) Quantitative study of flavonoids in leaves of Citrus plants. J Agric Food Chem 48(9): 3865-3871.

Sara Burt (2004) Essential oils: Their antibacterial properties and potential applications in foods: A review. International Journal of Food Microbiology 94(1): 223-253. 